\title{
Students' Attitude towards the use of CBT for UTME in Rural Secondary Schools. A Case of Guyuk LGA of Adamawa State, Nigeria
}

\author{
Afrifa James \\ Hannatu .G Moses \\ Babando Abdulrashid Aliyu \\ Department of Computer Science, \\ Department of Computer Science, \\ ICT Unit, Advanced Manufa. \\ Adamawa State Polytechnic, Yola \\ Nigeria \\ Adamawa State Polytechnic, Yola \\ Nigeria \\ Technology Programme \\ Jalingo, Nigeria
}

\begin{abstract}
This research investigated students' attitude towards the use of Computer Based Test (CBT) for Unified Tertiary Matriculation Examination (UTME) in rural secondary schools in Guyuk Local Government Area of Adamawa State. The population of the study comprises of 550 students in public schools who took 2018 UTME. This was randomly sampled from 5 selected public secondary schools in the study area. A five likert scale questionnaire comprises of 20 questions was used as instrument for data collection. Descriptive statistics was use to analyzed the data. The study revealed that most of the secondary schools in rural area do not have adequate facilities to teach and learn the use of computer and as a result it affected students' performance in 2018 CBT UTME. The study also revealed that CBT for UTME may hinder a brilliant candidate in the rural community, who has no computer knowledge, to gain admission into tertiary institutions in Nigeria. The study recommended that government should make more effort to support the teaching and learning of computer education in all secondary schools especially in the rural areas. The study also recommended that JAMB should make effort to open training CBT centers at the rural areas to enable candidates familiarize themselves with the use of computer and to curb posting candidates far from home because of insufficient computer centers.
\end{abstract}

Keywords: UTME, Computer Base Test, Paper Pencil Test, Computer Literacy, Rural Area

\section{INTRODUCTION}

The use of technology in education is being promulgated as a powerful tool that can transform education. The rapid advancement of Information and communication Technology (ICT) in teaching and learning has shifted the paradigm from Paper-Pencil based to computer- based system of examination, which are usually termed as Computer Based Testing (CBT). CBT is a form of assessment in which the computer is an integral part of question papers' delivery, response storage, marking of response or reporting of results from a test or exercise. [6] defined CBT as the use of computers for assessing students learning. It is required to think, re-consider, and modify or change the traditional test manners which include the use of paper pencil test (PPT). Electronic assessment tools had reduced the load of teachers and facilitate exams execution purposefully because of inclusion of ICTs in education. [13] defined CBT as an assessment that are administered by computer in either stand-alone devices linked to the internet or world-wide web (www.), most of them using multiple choice questions.

Student's prior knowledge and experience in computer and communication skills is essential in CBTs. CBT method may not suit the learning styles of many students particularly in the rural settlements that are faced with challenges of infrastructures, adequate facilities, manpower in teaching and learning of computer. The primary factor in determining whether an assessment program is beneficial or not depends on whether the assessment tasks are relevant to the purposes and learning outcomes for the course, not forgetting the attitudes and skills that are to be examined. This study 
investigated students' perceptions in rural areas and their attitudes towards the use of CBT in UTME.

[9] pointed out that with the advancement in technology, computerized testing has begun to be widespread and accepted by many schools. Joint admission and Matriculation board (JAMB) mulled the idea of migrating from PPT to a CBT about 8 years ago, the proposal then elicited some apprehension [5]. Between 1978 and 2012, JAMB conducted the national examination on a single Saturday using paper pencil test every year. In 2013, JAMB introduced the CBT alongside PPT. This continued in 2013 and 2014; and by 2015, the use of only CBT made compulsory. [10] opined that despite the advantages available in computerized test administration, it does not mean that CBTs are intrinsically better than the paper and pencil- tests. The restriction by JAMB that every candidate most registered CBT in UTME has led to lots of debate among Nigerians on whether it should be made optional or compulsory to all candidates. [2] opined that some major reasons for introducing CBT tests for UTME were to inhibit the rate of examination misconduct and also to speed up the release of results.

The acceptance and use of CBT are increasing each year. However, one unresolved problem associated with using CBT is performance bias due to examinees' differences [7]. The examinees' performance might be affected by computer experience and familiarity [12]. Introduction of CBT examinations in JAMB has attracted comments. [3] noted that some candidate failed CBT in JAMB UTME because of incompetence in use of computer and also noted that the epileptic power supply and poor level of economic situation in Nigeria are challenges that hinder effective use of CBT for UTM examinations in the present Nigerian situation. [3] identified power failures as a problem encountered in CBT in Nigeria.

[16] conducted a study on CBT: an assessment of students' perception of JAMB UTME in Nigeria. The finding revealed among others, that majority of the respondents confirmed that CBT can curb examination malpractice. Majority of candidates were also found to prefer CBT than the conventional way of writing examination. The Chisquare and
Pearson's correlation analysis showed that the respondents preferences for CBT was sensitive across gender, age distribution and student faculty. While improving electricity supply was identified as critical in enhancing CBT, poor ICT skill on the part of student were identified as the major problem facing the implementation of JAMB CBT. The study recommended the need for JAMB to create more awareness on CBT in order to ease the hurdle of JAMB examination. The study however does not cover the rural areas, [8] concluded that the eassessment can be justified in a number of ways. It helps to avoid the meltdown of current paper-based systems; it assesses valuable life skills; and it is better for users. For example, by provision on demand tests with immediate feedback and perhaps diagnostic feedback, and more accurate results via adaptive testing, helps improve the technical quality of tests by improving the reliability of scoring. Therefore, a proper preparation of the students for the examination via an introduction to the software could be a good method to curtail examinations malpractice effectively.

[15] compared traditional paper pencil testing to computer-based testing to measure the performance of 120 middle school students on multiple-choice and written test questions. The study found that students with prior computer experience, who were familiar with writing on computers, were more successful in writing computer responses. [4] investigated to several key factors in CBT versus PPT assessment. Factors of the study were content familiarity, computer familiarity, competitiveness, and gender. The study used a post-test designed with one factor and test mode (Computer-based and Paper-based). Students' score on 100-item multiple choice items and students' self-report on a distance learning survey were treated as dependent variables. Four sections of Computer Fundamental Course consisting of 105 students were selected as sample of the investigations. Results showed that CBT delivery impacted positively on students' scores as compared to PPT. The study found that the CBT group outperformed the PPT group. Gender, competiveness, and computer familiarity were not related to this performance difference, though content familiarity was. 
[14] assessed the degree of contribution of CBT among a number of students using questionnaire survey and the results revealed no serious effect. [11] studied the impact of CBT, PPT and mobile-based test on students' performance. A group of 38 students was experimented for 3 weeks and significant differences were found between the scores achieved by the students in second week, but not in first week. The study perceived that students had positive attitude towards CBT and assessment due to ease of use, comprehensive and instant feedback.

\section{METHODOLOGY}

The sample population of the study consisted of 550 students drawn from five secondary schools out of 14 public secondary schools in Guyuk Local Government Area of Adamawa State. The schools are Government Day Secondary School, Guyuk; Government Senior Secondary School, Banjaram; Government Day Senior Secondary School, Chikila; Government Day Senior Secondary School, Bruthin; and Government Day Senior Secondary School, Kola. The target population for the study comprises of candidates from the selected public schools who took the UTME in Yola Adamawa State. The names of public schools in the local government area that had candidates were obtained from the Local Government Education Board Authority Guyuk. The study adopted descriptive research design, the main method employed to collect data was questionnaire which was designed in two sections. Section A contained bio-data of the respondents, section B contained twenty items designed to elicit answer for columns, Strongly Disagreed, Disagreed, Undecided, Strongly Agreed and Agreed. Candidates who took the UTME were identified and administered questionnaires. 550 questionnaires were distributed to the respondents, 110 students from each selected secondary school. Data was analyzed with descriptive statistics.

\section{RESULTS AND DISCUSSION}

Table 1 is the list of secondary schools with the corresponding number of respondents in the study. Table 2 is the sampled questions with the corresponding results obtained from the respondents in a likert format. Table 3 is the value of each option selected by the respondents.
The ranking was done as postulated by [1] in equation 1

$5 x S D+4 x D+3 x U+2 x A+1 x S A$

Where $\mathrm{N}=550$

Table 1. Selected schools

\begin{tabular}{|l|l|l|l|l|}
\hline S/N & $\begin{array}{l}\text { Name of } \\
\text { schools }\end{array}$ & Village & $\begin{array}{l}\text { Local } \\
\text { Government }\end{array}$ & $\begin{array}{l}\text { Sampled } \\
\text { Respondents }\end{array}$ \\
\hline $\mathbf{1}$ & G.D.S.S S & Guyuk & Guyuk & 110 \\
\hline $\mathbf{2}$ & G.S.S.S & Banjeram & Guyuk & 110 \\
\hline $\mathbf{3}$ & G.D.S.S.S & Chikila & Guyuk & 110 \\
\hline $\mathbf{4}$ & G.D.S.S.S & Brutin & Guyuk & 110 \\
\hline $\mathbf{5}$ & G.D.S.S.S & Kola & Guyuk & 110 \\
\hline & & & Total & 550 \\
\hline
\end{tabular}

Table 2. Sampled Questions

\begin{tabular}{|c|c|c|c|c|c|c|}
\hline $\mathrm{s} / \mathrm{n}$ & ITEMS & SD & D & $\mathrm{U}$ & A & SA \\
\hline 1 & \begin{tabular}{l}
\multicolumn{3}{c}{ Computer } \\
Science is a \\
compulsory \\
subject in my \\
school
\end{tabular} & 257 & 101 & 0 & 109 & 83 \\
\hline 2 & $\begin{array}{l}\text { We have } \\
\text { Adequate } \\
\text { facilities to teach } \\
\text { and learn } \\
\text { computer in my } \\
\text { school }\end{array}$ & 201 & 215 & 0 & 53 & 81 \\
\hline 5 & $\begin{array}{l}\text { My school } \\
\text { administer } \\
\text { computer Base } \\
\text { Test to students } \\
\text { during exams }\end{array}$ & 316 & 43 & 0 & 11 & 10 \\
\hline 6 & \begin{tabular}{lr} 
CBT & favors \\
students with \\
prior computer \\
knowledge more \\
than \\
\multicolumn{2}{l}{ without computer } \\
experience
\end{tabular} & 12 & 22 & 0 & 302 & 211 \\
\hline 7 & $\begin{array}{l}\text { CBT curb } \\
\text { examination } \\
\text { malpractice and } \\
\text { enhance security }\end{array}$ & 29 & 16 & 0 & 318 & 187 \\
\hline
\end{tabular}




\begin{tabular}{|c|c|c|c|c|c|c|}
\hline 9 & $\begin{array}{l}\text { There is need for } \\
\text { adequate } \\
\text { computer training } \\
\text { for students in } \\
\text { the rural } \\
\text { settlement }\end{array}$ & 5 & 8 & 0 & 334 & 203 \\
\hline 12 & $\begin{array}{lr}\begin{array}{l}\text { You prefer to } \\
\text { write }\end{array} \text { JAMB } \\
\text { through } \\
\text { pencil } & \text { Test } \\
\text { PPT) } & \end{array}$ & 49 & 89 & 0 & 194 & 221 \\
\hline 15 & $\begin{array}{l}\text { Students at the } \\
\text { local } \\
\text { Government } \\
\text { faces challenges } \\
\text { writing CBT as a } \\
\text { result of } \\
\text { computer } \\
\text { illiteracy }\end{array}$ & 10 & 20 & 0 & 312 & 201 \\
\hline 18 & $\begin{array}{l}\text { CBT may hinder } \\
\text { a brilliant } \\
\text { candidates who } \\
\text { has no computer } \\
\text { knowledge to } \\
\text { gain admonition } \\
\text { into tertiary } \\
\text { institutions in } \\
\text { Nigeria }\end{array}$ & 22 & 63 & 0 & 273 & 192 \\
\hline 20 & $\begin{array}{l}\text { Posting } \\
\text { candidates far } \\
\text { from home as a } \\
\text { result of limited } \\
\text { CBT centers pose } \\
\text { problems of } \\
\text { accommodation } \\
\text { and mental } \\
\text { instability }\end{array}$ & 37 & 89 & 0 & 263 & 161 \\
\hline
\end{tabular}

\section{Ranking:}

Table 3 Ranking

\begin{tabular}{|l|l|l|}
\hline Ranking & Signifies & Responses \\
\hline 5 & SD & Strongly Disagree \\
\hline 4 & D & Disagree \\
\hline 3 & U & Undecided \\
\hline 2 & A & Agree \\
\hline 1 & SA & Strongly Agree \\
\hline
\end{tabular}

Item 1 in table 2 shows that 257 respondents strongly disagreed that Computer education is a compulsory subject at the secondary school level, 101 disagreed, 109 agreed, and 83 strongly agreed. Computation of the ranking in table 2 indicates 3.6, which shows that majority of the respondents disagreed that computer education is compulsory subject at the secondary school level. Item 2 in table 2 indicated that out of 550 respondents, 201 strongly disagreed that there are adequate facilities to teach and learn computer education, 215 disagreed, 53 agreed, and 81 strongly agreed. Computation of the ranking in table 2 shows 3.7, which indicated that majority of the respondents disagreed that schools have adequate facilities to teach and learn computer education.

Analysis of Item 5 in table 2 showed that, 316 respondents strongly disagreed that CBT is administer to students during exams, 213 disagreed, 11 agreed, and 10 strongly agreed. Computation of the ranking in table 2 shows 4.4, this affirmed that majority of the respondents strongly disagreed that CBT is administer to students during exams. Item 6 in table 2 shows that 12 respondents strongly disagreed that CBT favors students with prior computer knowledge more than these without computer experience, 12 disagreed, 305 agreed, and 211 strongly agreed. Computation of the ranking in table 2 indicates 1.5 , which shows that majority of the respondents agreed that CBT favors students with prior computer knowledge more than these without computer experience. Item 7 in table 2 shows that, 29 respondents strongly disagreed that CBT can curb examination malpractice and enhance security, 16 disagreed, 318 agreed, and 187 strongly agreed. Computation of the ranking in table 2 indicates 1.8 
which is close to 2, this affirmed that majority of the respondents agreed that CBT can curb examination malpractice and enhance security.

Item 9 in table 2 shows that 5 respondents strongly disagreed that there is need for adequate training for students in the rural settlement, 8 disagreed, 334 agreed, and 203 strongly agreed. Computation of the ranking in table 2 indicates 1.6 which is close to 2 , this affirmed that majority of the respondents agreed that that there is need for adequate training for students in the rural settlement.

Item 12 in table 2 indicated that 49 respondents strongly disagreed that they prefer to write JAMB through PPT, 86 disagreed, 194 agreed, and 221 strongly agreed. Computation of the ranking in table 2 indicates 2.1, which shows that majority of the respondents agreed that they prefer to write JAMB through PPT. Item 15 in table 2 shows that 10 respondents strongly disagreed that students at the local government face challenges in writing CBT as result of computer illiteracy, 27 disagreed, 201 agreed, and 312 strongly agreed. Computation of the ranking in table 1 indicates 1.5 , which is shows that majority of the respondents strongly agreed that students at the local government face challenges writing CBT as a result of computer illiteracy.

Item 18 in table 2 indicated that out of the 550 respondents 22strongly disagreed that CBT may hinder a brilliant candidate to gain admission into tertiary institution in Nigeria, 63 disagreed, 273 agreed, and 192 strongly agreed. Computation of the ranking in table 2 indicates 2.0, which shows that majority of the respondents agreed that CBT may hinder a brilliant candidate to gain admission into tertiary institutions in Nigeria. Item 20 in 2 indicates that 37 respondents strongly disagreed that posting students far from home as a result of limited CBT centers pose problems of accommodation and mental instability, 89 agreed, and 161 Agreed and 263 strongly agreed. Computation of the ranking in table 2 indicates 2.1, which is shows that majority of the respondents agreed that Posting candidates far from home as a result of limited CBT centers pose problems of accommodation and mental instability.

\section{CONCLUSION}

This study observed that candidates writing JAMB CBT from rural secondary schools are at disadvantage because of lack of computer knowledge. Therefore government should improve teaching and learning of computer education in all rural secondary schools and make it a compulsory subject. The results of the study shows that candidates from rural secondary schools writing JAMB CBT finds it difficult to perform well and meet the cut-off point for admission into the Nigeria universities. The results also revealed that most secondary schools in the rural areas lack adequate computer and internet facilities to prepare their candidate for CBT. The study further revealed that majority of the candidates from the rural schools has never taken CBT in their various schools and it also revealed that majority of the candidates prefer JAMB UMTE through PPT than CBT. It also affirmed that majority of the candidates agreed that posting them far from home as a result of limited JAMB CBT centers pose problems of accommodation and mental instability.

\section{RECOMMENDATIONS}

1. The government should make more effort to ensure that computer education is made compulsory in all schools and adequate facilities should be provided to support the teaching and learning of the subject especially rural secondary schools.

2. Curriculum planners should make practical computer education from Primary school to Secondary Education levels compulsory to make students proficient in use of computer operations for UTME.

3. Local Government Education Authority should make effort to support rural schools by providing them with computers, generators, Facilities and manpower without necessary waiting for support from the state Government.

4. JAMB should make effort to open training centers at the rural area for candidates who has no computer knowledge and CBT centers for UTME to curb 
posting candidates far from home because of insufficient computer centers.

\section{ACKNOWLEDGMENTS}

Our thanks to Dr B.Y Baha, HOD Information Technology, Modibbo Adama University of Technology, Yola for his inspiration and encouragement. Our appreciation also to Dr N. Oye HOD, Computer Science Department Modibbo Adama University of Technolgy, Yola for his professional advice.

\section{REFERENCES}

[1] Abeysekera, S. (2001) Analysis approaches in participatory work involving ranks or scores DFID theme paper (revised). UK: Statistics Services Center, University of Reading

[2] Abubakar, A.S. \& Adebayo O, F.O. (2014).Using computer based test method for the conduct of examination in Nigeria: Prospects, challenges and strategies. Mediterranean journal of Social Sciences, 5(2) 47 ISSN 203912117 retri d.http://www.nuhafoundationorg/home/biog/biog gingentrie s/2013/adultchangingthemode07.cond ucting examinations in Nigeria buazie\#.

[3] Adebayo, F. (N.D).Candidates list out the advantage and disadvantages for computerBased UTME Retrieved May, 2015 from www.google.com

[4] Bodmann, S. M. and Robinson, D. H. (2004). Speed and Performance Differences among Computer Based and Paper- Pencil Tests, Journal of Educational Computing Research, 31(1): $51-60$.

[5] Chijioke O, (2015) the Guardian 26 June 2015.

[6] Conole, G. \& Warburton, B. (2005).A Review of computer-assisted assessment.Research In Learning Technology,13(1), 17-31.

[7] FairTest: The National Center for Fair and Open Testing, (2007). Computerized Testing: More Questions than Answers. Retrieved on June 26, 2017 from http://www.fairtest.org/ Computerized-testing- more-questions answers
[8] Jim R. and Sean, M., (2004).Literature Reviews of E-assessment. Future lab Series, Report10; ISBN: 0-9544695- 85. Retrieved on October 4th 2018 from http://hal.archives ouvert es.fr/docs/00/19/04/40/PDF/ridgway-j-2004r10.pdf.

[9] Haggins,J., Rusell, M., Huffma, T., (2005) Examining the effect of Computer-Based Passage Presentation on Reading Test Performance. The Journal of Technology, Learning and Assessment Vol 3, number 4 January 2005

[10] John CK, Cynthia GP, Judith AS,Tim D (2002). Practical Considerations in Computer-Based Testing.Sheridan Books. Lawrence Erlbaum Associates, New Jersey,USA.

[11] Karadeniz, S. (2009). The impacts of paper, web and mobile based assessment on students' achievement and perceptions. Scientific Research.

[12] McDonald, A. (2002). The impact of individual differences on the equivalence of computer Based and paper- and pencil educational assessments. Computers \& Education Journal, 39(3), 299-312.

[13] Oduntan, O.E. Ojuawo O.O. \& Odutan E.A (2015). A comparative analysis of students' performance in paper/pencil test (PPT) and computer based test (CBT) Examination system. Research Journal of Education studies and Review, (I) 24-29. Retrieved November 2018 from www.google.com.

[14] Powers, D.E. \& O’Neill, K (2006). Inexperienced and anxious computer users: coping with a computer- administered test of academic skills. Education Assessment .1(2), 153-173.

[15] Russell, M., \& Haney, W. (1997).Testing writing on computers: An experiment comparing student performance on tests conducted via computer and via paper and pencil, Education Policy Analysis Archives, 5 (3) test mode effect,British Journal of Educational Technology, 33 (5): 593-602.

[16] Sanni A.A. Mohammad M.F (2015). Computer Based Testing (CBT): An Assessment of Student Perception of JAMB UTME in Nigeria. Computing, Information System, Development And Allied Research Journal Vol. 6,June2015www.cisdijournal.net 